
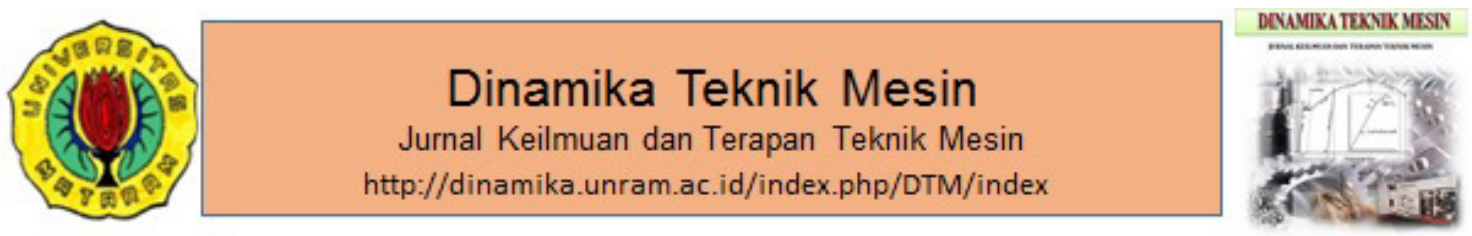

\title{
Evaluasi efektifitas effective microorganism-4 (EM-4) dalam menaikkan volume produksi biogas
}

\author{
H.S. Tira*, Syahrul, E.G. Umbara
}

Teknik Mesin Fakultas Teknik Universitas Mataram, Jln. Majapahit No. 62 Mataram Nusa Tenggara Barat Kode Pos : 83125, Telp. (0370) 636087; 636126; ext 128 Fax (0370) 636087.

*Email: hendrytira@unram.ac.id

\section{ARTICLE INFO}

Article History:

Received 29 September 2017

Accepted 1 November 2017

Available online 1 january 2018

Keywords:

EM-4

Biogas volume

Anaerobic digestion

\section{ABSTRACT}

Anaerobic digestion process of cow dung was observed over 30 days with addition of effective microorganism - 4 in regard to improve biogas production volume. Temperature for biogas production was kept constant and was conducted at mesophilic mode. It was found that EM4 addition effectively increased the biogas yields production. The improvement of biogas volume was recorded as high as $87.8 \%$ which was achieved in $10 \%$ V/v EM-4 addition. However, the solution concentration should be limited in certain amount. With these experiments, the results showed that the addition of EM-4 into the digester resulted in a gradual decrease in the volume of biogas. The most influential factor of the result may be attributed by the alteration of digestate $\mathrm{pH}$ from netral to more acidic. This acidic condition hampered microorganism to do anaerobic process well.

\section{PENDAHULUAN}

Permasalahan ketersedian energi yang cukup telah dihadapi oleh Indonesia sejak beberapa dekade terakhir. Beberapa hal yang menjadi pemicunya antara lain adalah pertumbuhan jumlah penduduk dan industri yang pesat tetapi tidak diimbangi dengan penyediaan energi yang cukup. Ketergantungan terhadap bahan bakar fosil seperti minyak bumi, batu bara, dan gas alam sangat besar. Selain itu di pedesaan dan daerah terpencil masih ditemukan penggunaan kayu sebagai bahan bakar. Pola pemakaian bahan bakar tersebut telah menimbulkan berbagai efek buruk seperti meningkatnya polusi lingkungan dan rusaknya lingkungan hidup.

Dalam mengatasi dampak buruk tersebut maka telah dilakukan berbagai usaha seperti mencari dan mengembangkan berbagai sumber energi alternatif. Tujuan yang ingin dicapai melalui usaha tersebut adalah untuk mengurangi ketergantungan terhadap bahan bakar fosil dan sekaligus menciptakan energi yang murah, mudah diperoleh dan ramah lingkungan. Salah satu sumber energi terbarukan tersebut adalah biogas. Biogas adalah bentuk energi terbarukan yang yang berasal dari proses fermentasi limbah organik baik yang berasal dari tumbuhan maupun hewan. Biogas terdiri dari gas metana $\left(\mathrm{CH}_{4}\right)$ sebesar $49 \%$, karbon dioksida $\left(\mathrm{CO}_{2}\right)$ sebesar $45 \%$, hidrogen $\left(\mathrm{H}_{2}\right)$ sebesar $1-5 \%$, oksigen $\left(\mathrm{O}_{2}\right)$ sebesar $0,1-0,5 \%$, hidrogen sulfida $\left(\mathrm{H}_{2} \mathrm{~S}\right)$ sebesar $0-3 \%$, dan impuritas lain (Fadli, 2013).

Dalam berbagai upaya untuk menghasilkan biogas terdapat sebuah kendala yaitu rendahnya kuantitas volume biogas yang dihasilkan. Masalah ini menyebabkan upaya memproduksi dan mengenalkan biogas ke masyarakat sedikit 
terhambat karena jumlah volume biogas yang akan digunakan lebih besar dari pada yang diproduksi oleh digester.

Penelitian ini dilakukan untuk dapat meningkatkan produksi biogas. Penelitian dilakukan dengan menambahkan effective microoragnism-4 (EM-4) yang biasa digunakan untuk membantu proses penyerapan atau persediaan unsur hara dalam tanah. Kandungan mikroorganisme yang terdapat di dalam EM-4 diharapkan membantu bakteri saccharomyces cerevisiae untuk menghasilkan biogas yang lebih banyak.

\section{METODE PENELITIAN}

Sebelum melakukan penelitian semua alat dan bahan dikumpulkan. Sebelum kotoran sapi dimasukkan ke dalam digester, terlebih dahulu kotoran sapi dicampur dengan air kemudian ditambahkan dengan EM-4 dengan persentasi sebesar $0,5,10,15,20$, dan $40 \%$ basis volume terhadap jumlah air yang digunakan. Variabel tersebut kemudian disebut $\mathrm{V}_{1}, \mathrm{~V}_{2}, \mathrm{~V}_{3}, \mathrm{~V}_{4}$, dan $\mathrm{V}_{5}$. Adapun volume air yang digunakan sebesar 13 liter. Setiap substrat yang telah disiapkan kemudian dimasukkan ke dalam 5 buah digester yang berbeda. Digester yang digunakan terbuat dari jerigen plastik bervolume 35 liter. Dengan demikian masih terdapat setengah ruang kosong untuk penampungan sementara biogas yang dihasilkan sebelum dialirkan ke dalam ruang penampung guna pengukuran volume. Digester juga diisolasi menggunakan tanah untuk menjaga temperatur selama fermentasi relatif konstan. Hal ini untuk menghindari pengaruh temperatur terhadap proses perkembangbiakan bakteri dalam menghasilkan biogas. Skema digester yang digunakan dapat dilihat pada Gambar 1.

Proses digestifikasi anaerob dilaksanakan selama 30 hari dan selama itu pula beberapa pengamatan dan pengukuran dilakukan seperti: temperatur digester, $\mathrm{pH}$ substrat sebelum dan sesudah fermentasi, dan volume biogas yang dihasilkan. Pengukuran volume biogas dilakukan dengan menggunakan metode perpindahan volume (volume displacement method). Adapun rancangan alat pengukur volume tersebut ditunjukkan pada Gambar 2. Biogas akan dimasukkan ke dalam pipa 1 sementara pipa 2 diisi dengan air. Perbedaan ketinggian antara pipa merupakan volume dari biogas yang diukur. Pada pipa 1 dipasang katrol untuk mengangkat pipa tersebut agar biogas dengan mudah masuk ke dalam pipa.

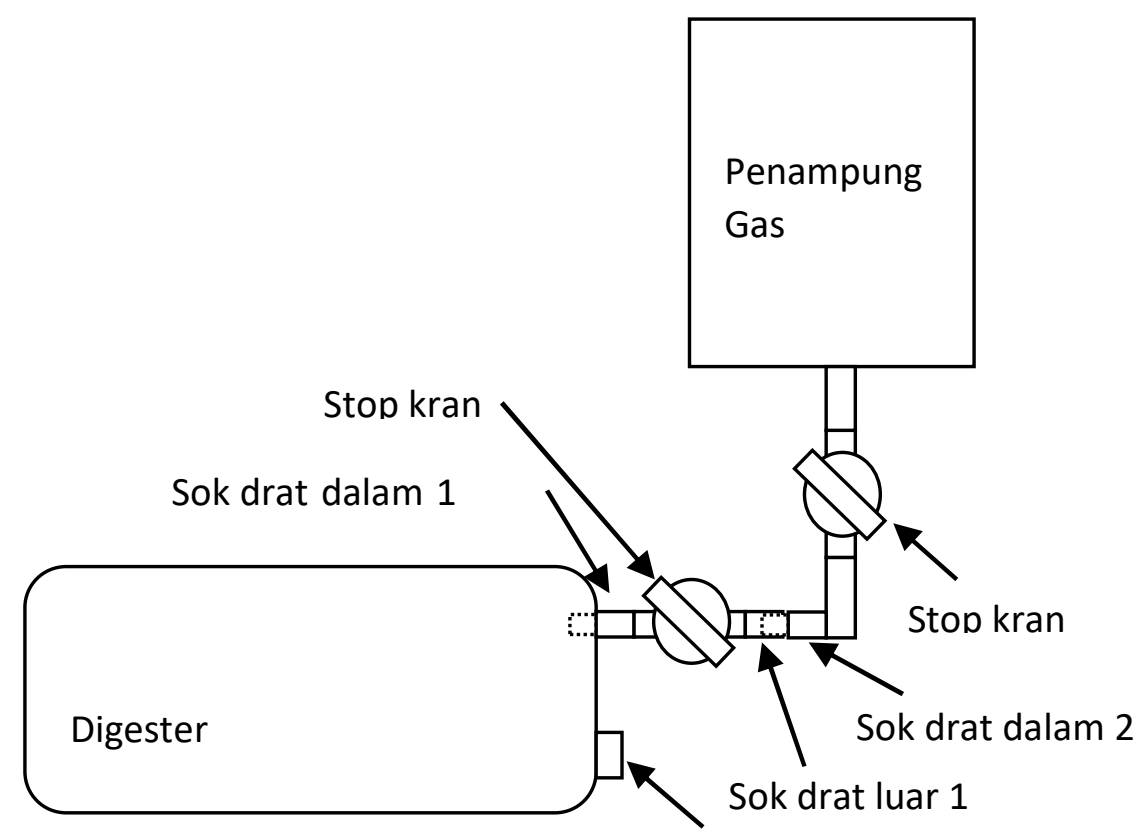

Input kotoran sapi

Gambar 1. Desain alat penelitian 

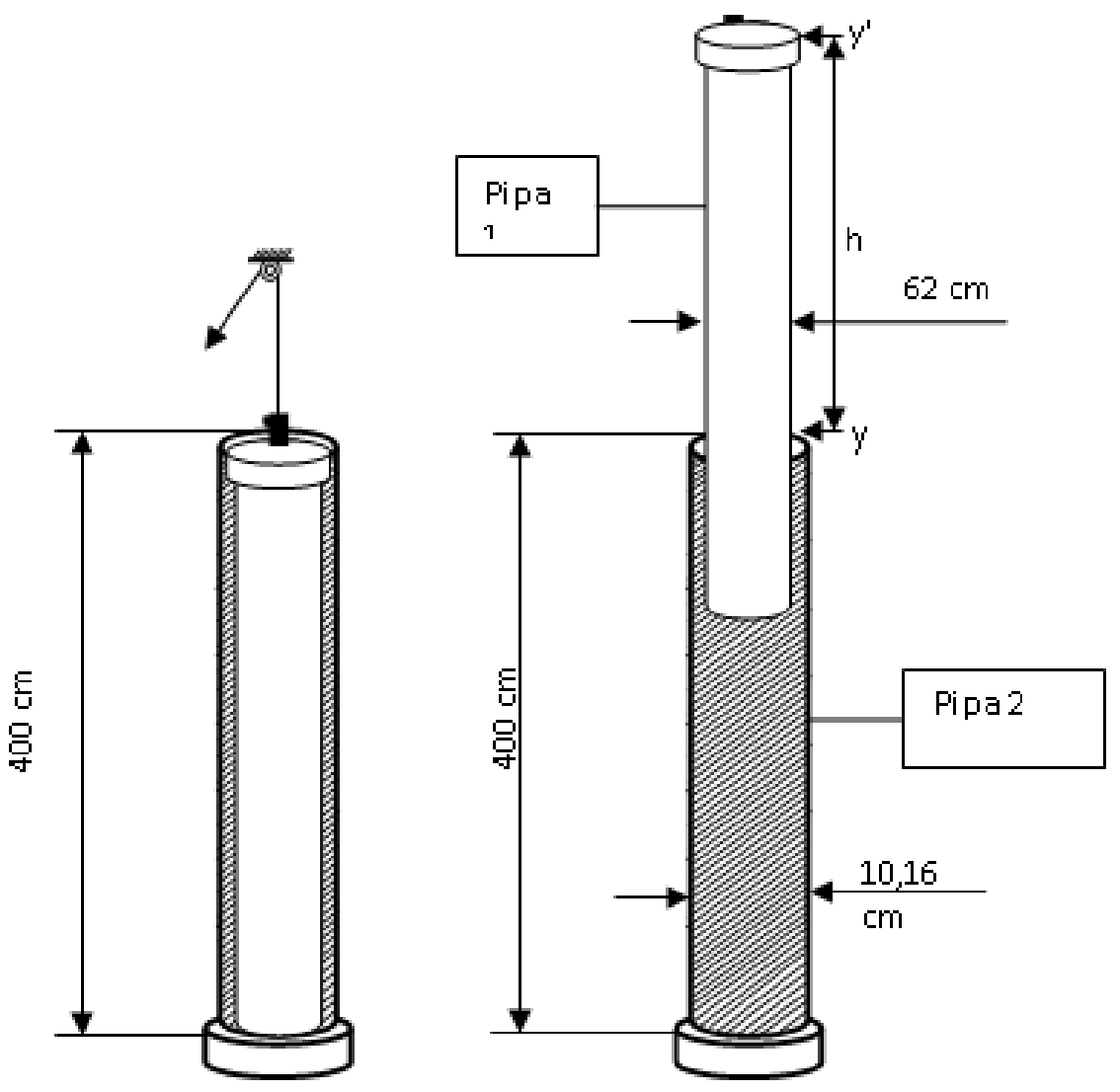

Gambar 2. Rangkaian alat ukur

\section{HASIL DAN PEMBAHASAN}

\section{Pengaruh EM-4 Terhadap pH}

Penelitian ini diawali dengan pencampuran bahan baku sesuai variabel, kemudian memasukkannya kedalam digester untuk mengalami proses fermentasi secara anaerob. Sebelum dimasukkan ke dalam digester, substrat (bahan baku) terlebih dahulu diukur nilai pHnya. Kemudian setelah 30 hari kembali dilakukan pengukuran niai $\mathrm{pH}$ kembali, untuk mengetahui nilai $\mathrm{pH}$ akhir setelah substrat mengalami proses fermentasi anaerob. Hasil Pengukuran $\mathrm{pH}$ dapat dilihat pada Gambar 3.

Hasil yang diperoleh menunjukkan pengaruh EM-4 dapat menurunkan $\mathrm{pH}$ substrat. Penurunan tersebut dikarenakan EM-4 memiliki nilai $\mathrm{pH}$ sebesar 3,73 sehingga semakin banyak penambahan EM-4 pada substrat, maka nilai pHnya akan menurun. Pada Substrat $V_{6}$ memiliki nilai $\mathrm{pH}$ yang sangat rendah yaitu 5,5 . Tapi pada kasus ini, biogas masih dapat berproduksi dikarenakan kisaran $\mathrm{pH}$ produksi biogas antara 5,5
- 8,5 dan biogas akan menghentikan produksinya bila substrat dalam keadaan asam berlebih dengan nilai pH dibawah 5 (Perdana, 2009).

Penurunan $\mathrm{pH}$ yang terjadi menunjukkan adanya proses degradasi senyawa organik. Pada awal proses fermentasi $\mathrm{pH}$ akan selalu turun karena sejumlah mikroorganisme tertentu akan mengubah sampah organik menjadi asam-asam organik (Astutii, 2013). Selain itu, komposisi bahan yang digunakan dapat mempengaruhi nilai $\mathrm{pH}$. Demikian pula semakin lama waktu fermentasi, nilai pH larutan meningkat kembali (Amaru, 2004).

\section{Pengaruh Kondisi Operasi Reaktor Terhadap Temperature Biogas}

Kondisi operasi reaktor menjadi salah satu hal yang penting dalam proses fermentasi. Reaktor yang bagus harus mampu memberikan kondisi operasi yang stabil dan tidak terpengaruh oleh lingkungannya (Megawati, 2014).

Temperatur tersebut merupakan kondisi mikroorganisme tumbuh dan berkembang secara optimal. Temperatur juga dapat mempengaruhi pertumbuhan dari bakteri methanogen (Darmanto, 
2012). Temperatur berperan penting dalam mengatur jalannya reaksi metabolisme bagi bakteri. Temperatur yang lebih tinggi dari temperatur yang dapat ditoleransi akan menyebabkan protein dan komponen esensial lainnya rusak sehingga sel akan mati. Demikian pula bila temperatur berada di bawah batas toleransi, transportasi nutrisi akan terhambat dan proses kehidupan sel akan terhenti. Oleh karena itu, temperatur sangat berpengaruh terhadap pertumbuhan bakteri methanogen. Bakteri methanogen yang termasuk bakteri mesofil yaitu bakteri yang dapat hidup dalam suhu optimum yang berkisar pada suhu $20-40^{\circ} \mathrm{C}$.

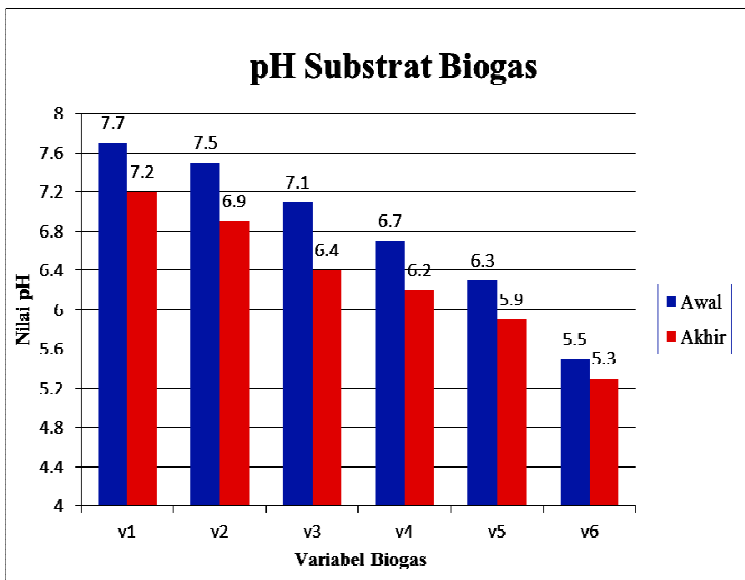

Gambar 3. Kurva perbandingan $\mathrm{pH}$ awal dan $\mathrm{pH}$ akhir

Suhu dalam reaktor cenderung mengalami fluktuasi. Fluktuasi ini disebabkan karena pada proses dekomposisi bahan organik menghasilkan air yang dapat menurunkan suhu. Sedangkan kenaikan suhu dikarenakan proses dekomposisi bahan organik bersifat eksoterm. Meningkatnya suhu menandakan bahwa telah terjadi proses dekomposisi bahan organik. Penguraian bahan organik akan menghasilkan gas metan, $\mathrm{CO}_{2}$, sejumlah trace gas, dan panas. Temperatur merupakan faktor lingkungan yang penting dalam akitivitas mikroorganisme pada proses biologis secara anaerob. Oleh karena itu hasil pengukuran terhadap temperatur, cenderung mengikuti temperatur lingkungan berkisar antara $27-30^{\circ} \mathrm{C}$ (Haryati, 2006).

\section{Pengaruh EM-4 Terhadap Volume Biogas}

Volume biogas yang terbentuk dihitung menggunakan persamaan sebagai berikut:

$$
\text { Dimana } \begin{aligned}
\mathrm{V} & =1 / 4 \cdot \pi \cdot \mathrm{D}^{2} \cdot \mathrm{h} \\
\mathrm{V} & =\text { Volume biogas } \\
\Pi & =3,14 \\
\mathrm{D} & =\text { Dimeter pipa } 1(7,62 \mathrm{~cm})
\end{aligned}
$$

$$
\mathrm{h}=\text { Perubahan ketinggian pada pipa } 1
$$

Berdasarkan variasi penambahan EM-4 diperoleh volume biogas terbesar pada variabel $\mathrm{V}_{3}$, yaitu pada hari ke 15 yaitu sebesar 4,79 liter (Gambar 4). Hasil penelitian ini menunjukkan bahwa penambahan EM-4 dapat menaikkan volume biogas yang dihasilkan. Hal ini disebabkan karena aktifitas EM-4 yang terdiri atas Lactobacillus, Actinomycetes dan jamur. Fungsi mikroorganisme diduga melakukan delignifikasi, menurunkan derajat polimerisasi selulosa dan hidrolisis hemiselilosa. Penambahan EM-4 mempercepat degradasi selulosa dan hemiselilosa dan lignin menjadi senyawa yang dibutuhkan oleh senyawa penghasil biogas, sehingga produksi biogas meningkat (Herawati, 2010).

Penambahan EM-4 dapat mempercepat proses fermentasi sehingga dapat mempercepat pembentukan biogas. Sedangkan variabel $V_{1}$ tanpa penambahan EM-4 yang mencapai puncak produksinya lebih lama, yaitu pada hari ke 24 dengan volume yang dihasilkan sebesar 2,10 liter. Biogas kotoran ternak sapi (tanpa penambahan EM-4) mencapai puncak produksinya pada hari ke 20-25. Selanjutnya diikuti dengan variabel $V_{2}, V_{4}$, $\mathrm{V}_{5}$, dan $\mathrm{V}_{6}$

Variabel $V_{6}$ menghasilkan biogas yang rendah oleh karena oleh nilai $\mathrm{pH}$ substrat yang sangat rendah yaitu 5,5. Pada umumnya bakteri penghasil metan sensitif terhadap perubahan $\mathrm{pH}$ dan mempunyai kisaran $\mathrm{pH}$ optimum antara 6,58,5. Dibawah $\mathrm{pH}$ ini penguraian dapat berjalan tetapi efisiensi penguraian akan turun dengan cepat dan akan menghasilkan kondisi asam yang akan menghambat pertumbuhan bakteri metanogenetik. Jika pertumbuhan bakteri metan terhambat, laju penguraian asam volatil akan berkurang sehingga akan terjadi akumulasi asam volatil (Sumady, 2015).

Selain itu, ketersediaan unsur mikronutrien dan makronutrien yang tinggi pada substrat $V_{6}$, disebabkan oleh penambahan EM-4 yang terlalu banyak menyebabkan hambatan dan gangguan dalam proses fermentasi anaerob, yang berdampak pada menurunnya produksi biogas. Mikronutrien (trace elements) seperti besi, nikel, kobal, selenium, molibdenum atau tungsten dan makronutrient seperti karbon, nitrogen, fosfor, dan belerang berguna untuk pertumbuhan dan kelangsungan hidup mikroorganisme anaerobik. Bila ketersediaannya terlalu banyak akan menghambat dan mengganggu dalam proses pencernaan digester anaerob (Aji, 2015). 


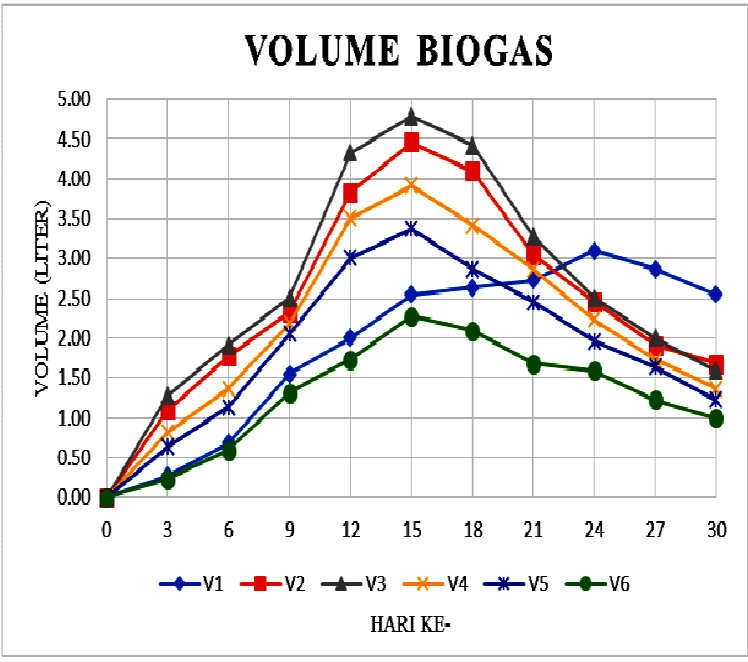

Gambar 4. Kurva volume biogas

\section{Laju Pembentukan Biogas}

Dari Gambar 5 dapat dilihat bahwa Effective Mikroorganisme-4 memegang peranan penting dalam proses fermentasi biogas. Dari kurva didapatkan rata-rata laju pembentukan biogas tertinggi pada variabel EM- $4 \mathrm{~V}_{3}$ yaitu 0,87 liter/hari sedangkan pada variabel tanpa penambahan EM4 , $\mathrm{V}_{1}$, yang hanya memiliki rata-rata laju pembentukan biogas 0,64 liter/hari. Namun untuk penambahan EM-4 yang cukup tinggi pada variabel EM-4 V6, rata-rata laju pembentukan biogasnya cukup rendah yaitu 0,42 liter/hari. Hal ini sesuai dengan pernyataan Siboro (2013) yaitu penggunaan EM-4 yang cukup banyak dapat menurunkan kualitas biogas yang dihasilkan.

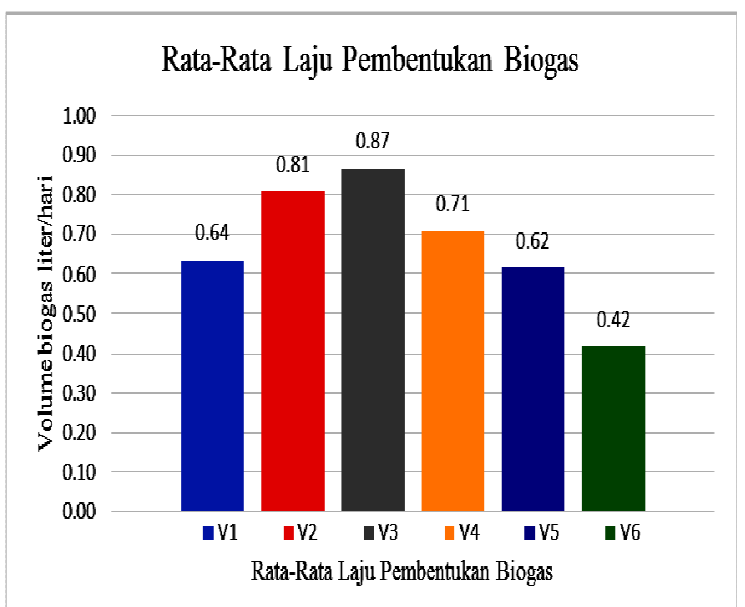

Gambar 5. Kurva rata-rata laju pembentukan biogas

Perhitungan laju pembentukan biogas bertujuan untuk mengetahui volume biogas yang terbentuk setiap harinya pada masing-masing tabung digester. Laju pembentukan biogas dapat dihitung menggunakan rumus:

$$
\overline{\mathrm{V}}=\mathrm{V} / \text { hari }
$$

Dimana:

$$
\begin{array}{ll} 
& =\text { Laju pembentukan biogas } \\
V & =\text { Volume biogas yang terbentuk } \\
\text { Hari } & =3
\end{array}
$$

\section{KESIMPULAN}

Adapun kesimpulan yang didapat setelah melakukan penelitian tentang pengaruh penambahan effective mikroorganisme-4 (EM-4) pada pembuatan biogas kotoran ternak sapi adalah sebagai berikut :

1. Penambahan EM-4 dapat menurunkan nilai $\mathrm{pH}$ substrat.

2. Volume terbesar dihasilkan pada variabel $\mathrm{V}_{3}$ penambahan EM-4 10\% sebesar 4,79 liter. Sedangkan variabel $V_{1}$ tanpa penambahan $E M-$ 4 volume terbesar yang dihasilkan yaitu sebesar 3,10 liter. Akan tetapi, penambahan EM-4 yang terlalu banyak pada variabel $V_{6}$ (penambahan EM-4 40\%) justru mampu menurunkan produksi biogas.

3. Penambahan EM-4 pada kotoran ternak sapi dapat mempercepat proses fermentasi sehingga dapat mempercepat proses pembentukan biogas, dengan hasil terbaik pada Variabel $V_{3}$ (penambahan EM-4 10\%) yang mencapai puncak produksinya pada hari ke- 15 . Sedangkan variabel $V_{1}$ mencapai puncak produksinya pada hari ke-24.

4. Rata-rata laju pembentukan biogas per hari tertinggi dihasilkan oleh variabel $V_{3}$ (penambahan EM-4 10\%) yaitu 0,87 liter/hari dan rata-rata laju pembentukan biogas perhari terrendah dihasilkan oleh variabel $V_{6}$ yaitu 0,42 liter/hari.

\section{DAFTAR PUSTAKA}

Aji K.W., 2015, Pengaruh penambahan EM-4 (effective microoragism-4) pada pembuatan biogas dari eceng gondok dan rumen sapi, Universitas Negeri Semarang, Semarang.

Amaru K., 2004, Rancang bangun dan uji kinerja biodigester plastic polyethylene skala kecil, Fakultas pertanian, Universitas padjajaran.

Astuti, Farida K., 2013, Teknologi fermentasi pembuatan pakan alternatif dari lumpur organik unit gas bio dengan penambahan EM-4 dan air, Tugas Akhir, Universitas Brawijaya.

Darmanto A., 2012, Pengaruh kondisi temperatur mesophilic $\left(35^{\circ} \mathrm{C}\right)$ dan thermophilic $\left(55^{\circ} \mathrm{C}\right)$ anaerob digester kotorann kuda terhadap 
produksi biogas, Fakultas Teknik, Universitas Brawijaya, Malang.

Fadli, Dian, 2013, Kaji eksperimental sistem penyimpanan biogas dengan metode pengkompresian dan pendinginan pada tabung gas sebagai bahan bakar penggaanti gas LPG, Fakultas Teknik, Universitas Mataram, Mataram.

Haryati T., 2006, Biogas: limbah peternakan yang menjadi sumber energi alternatif, Balai Penelitian Ternak, Bogor.

Herawati D.A., 2010, pengaruh pretreatment jerami padi pada produksi biogas dari jerami padi dan sampah sayur sawi hijau secara batch, Tugas Akhir, Universitas Setia Budi.

Megawati, Aji K.W., 2014, Pengaruh penambahan EM-4 (effective microoragism-4) pada pembuatan biogas dari eceng gondok dan rumen sapi, Univesitas Negeri Semarang.

Perdana A., 2009. Sumber energi non fosil, Tersedia di:https:// perdanaangga. Wordpress .com /2009/07/10/sumberenergi-alternatif-non-fosil/. Akses 10 juli 2009.

Siboro E.S., 2013, Pembuatan pupuk cair dan biogas dari campuran limbah sayuran, Universitas Sumatera Utara, Medan.

Sumady D.R., 2015, Pengaruh suhu, rasio C/N dan penambahan bioaktivator EM-4 terhadap produksi biogas dari sampah buah-buahan, Tugas akhir, Universitas Syarif Hidayatullah, Jakarta. 